\title{
Neoboletus antillanus sp. nov. (Boletaceae), first report of a red-pored bolete from the Dominican Republic and insights on the genus Neoboletus
}

\author{
Matteo Gelardi', Claudio Angelini2 ${ }^{2,3}$, Federica Costanzo', Francesco Dovana ${ }^{4}$, \\ Beatriz Ortiz-Santana ${ }^{5}$, Alfredo Vizzini ${ }^{4}$
}

I Via Angelo Custode 4A, I-00061 Anguillara Sabazia, RM, Italy 2 Via Cappuccini 78/8, I-33170 Pordenone, Italy 3 National Botanical Garden of Santo Domingo, Santo Domingo, Dominican Republic 4 Department of Life Sciences and Systems Biology, University of Turin, Viale P.A. Mattioli 25, I-10125 Torino, Italy 5 US Forest Service, Northern Research Station, Center for Forest Mycology Research, One Gifford Pinchot Drive, Madison, Wisconsin 53726, USA

Corresponding author: Alfredo Vizzini (alfredo.vizzini@unito.it)

Academic editor: M.P. Martín | Received 18 January 2019 | Accepted 12 March 2019 | Published 29 March 2019

Citation: Gelardi M, Angelini C, Costanzo F, Dovana F, Ortiz-Santana B, Vizzini A (2019) Neoboletus antillanus sp. nov. (Boletaceae), first report of a red-pored bolete from the Dominican Republic and insights on the genus Neoboletus. MycoKeys 49: 73-97. https://doi.org/10.3897/mycokeys.49.33185

\begin{abstract}
Neoboletus antillanus sp. nov. appears to be the only red-pored bolete known from the Dominican Republic to date. It is reported as a novel species to science based on collections gathered in a neotropical lowland mixed broadleaved woodland. A detailed morphological description, color images of fresh basidiomes in habitat and line drawings of the main anatomical features are provided and relationships with phylogenetically and phenotypically similar taxa are discussed. Three genomic regions (nrITS, nrLSU/28S and $r p b 2$ ) have been sequenced in order to reinforce the recognition of the new species and to elucidate its taxonomic affiliation within Neoboletus.
\end{abstract}

\section{Keywords}

Boletales, molecular phylogeny, Greater Antilles, neotropical boletes, Sutorius, taxonomy

Copyright Matteo Gelardi et al. This is an open access article distributed under the terms of the Creative Commons Attribution License (CC BY 4.0), which permits unrestricted use, distribution, and reproduction in any medium, provided the original author and source are credited. 


\section{Introduction}

In recent times the intensive use of molecular tools applied to the investigation of the systematics of boletoid mushrooms and related groups (order Boletales) has dramatically revolutionized traditional classifications based on morphological traits, facilitating the research process and leading to the establishment of a novel scientific approach with unexpected taxonomic implications (Bruns and Palmer 1989, Binder 1999, Binder and Bresinsky 2002, Binder et al. 2005, Binder and Hibbett 2006, Nuhn et al. 2013, Wu et al. 2014).

In particular, members of the Boletaceae have undergone an extensive reassessment and several new genera have arisen from large, unwieldy and definitely polyphyletic assemblages such as Boletus Fr., Xerocomus Quél. and Tylopilus P. Karst, just to name a few (Wu et al. 2016b). Among these genera, Neoboletus Gelardi, Simonini \& Vizzini has recently been segregated from Boletus s.l. (Vizzini 2014), to include taxa orbiting around the generic type Boletus luridiformis Rostk. that were traditionally assigned to either the polyphyletic Boletus sect. Luridi Fr. emend. Lannoy \& Estadès (Lannoy and Estadès 2001), Boletus sect. Erythropodes Galli pro parte (Galli 2007) or Boletus subg. Luridellus sect. Immutabiles and sect. Luridiformes pro parte (nom. inval., art. 39.1) (Watling and Hills 2005). Species included in Neoboletus are characterized by boletoid to rarely secotioid habit, tomentose to velvety pileus, yellow-olive tubes, brownish, red to orange or more rarely yellow pores, stipe surface usually finely dotted-punctate, yellowish context, tissues quickly and intensely bluing on handling or exposure, mild taste, olive-brown spore print, ellipsoid-fusiform, smooth basidiospores, trichodermal pileipellis consisting of filamentous hyphae, hymenophoral trama of the "Boletus-type", fertile caulohymenium, inamyloid hyphae in the stipe trama, gymnocarpic ontogenetic development and ectomycorrhizal (ECM) association with members of the Pinaceae and Fagaceae (Vizzini 2014, Simonini and Vizzini 2015, Bessette et al. 2016, Wu et al. 2016a). The separation of Neoboletus from Boletus s. str. and its establishment at the generic rank is phylogenetically strongly supported (Binder and Hibbett 2006, Mello et al. 2006, Halling et al. 2007, 2015; Desjardin et al. 2009, Li et al. 2011, Zeng et al. 2012, Gelardi et al. 2013, 2015; Nuhn et al. 2013, Trappe et al. 2013, Arora and Frank 2014, Vizzini et al. 2014, Wu et al. 2014, Zhao et al. 2014, 2015; Zhu et al. 2014, Chakraborty et al. 2015, Simonini and Vizzini 2015, Smith et al. 2015, Urban and Klofac 2015, Henkel et al. 2016, Liang et al. 2016, Orihara and Smith 2017), the genus being tentatively placed in the "Pulveroboletus group" (Wu et al. 2014), although its taxonomic placement within the Boletaceae still remains uncertain (Nuhn et al. 2013, Wu et al. 2014).

In contrast to the well-known bolete heritage of North America, Europe and to a lesser degree East Asia, the diversity of the fleshy pored mushrooms in the neotropical forests of Central America and adjacent regions have received only relatively limited attention (e.g. Dennis 1970, Singer et al. 1983, 1990, 1991, 1992; Gómez and Singer 1984, Singer and Gómez 1984, Halling 1989, 1997; Gómez 1997, Halling et al. 1999, 2004, 2008, 2012a, b; Flores Arzù and Simonini 2000, Franco-Molano et al. 2000, Halling and Mueller 2002, 2003, 2005; Mata et al. 2003, Mueller et al. 2006, Halling and Ortiz-Santana 
2009, Flores Arzù et al. 2012, García-Jiménez 2013, although there are many others). Particularly the Caribbean appear to be little explored from the mycological perspective; information is generally widely dispersed and members of the Boletales (including also lamellate and sequestrate representatives) have only sporadically been reported over the past two centuries (Berkeley and Curtis 1869, Hitchcock 1898, Patouillard 1900 1902; Murrill 1910, 1918, 1921; Baker and Dale 1951, Dennis 1970, Kreisel 1971, Singer and Fiard 1976, Reid 1977, Hosford and Trappe 1980, Alphonse 1981, Pegler 1983, 1987; Miller et al. 2000, Guzmán et al. 2004, Camino Vilaró et al. 2006, Ortiz-Santana 2006, Courtecuisse and Welti 2013, Lécuru and Courtecuisse 2013, Moreau et al. 2013). In the Dominican Republic (Hispaniola), as far as the boletoid fungi are concerned and aside from the recent settlement of the genus Phylloporopsis Angelini et al. based on Phylloporus boletinoides A.H. Smith \& Thiers (Farid et al. 2018) and a few other reports of boletes annotated in general publications (Minter et al. 2001, Lodge et al. 2001), the monographic treatment of Ortiz-Santana et al. (2007) currently remains the sole and as yet most comprehensive taxonomic account dealing with the Boletaceae and Suillaceae for this country.

Neoboletus antillanus is described herein as a new species to science using morphological and three-loci (nrITS, nrLSU/28S and rpb2) molecular data, based on multiple collections from a lowland mixed woodland consisting of a number of different neotropical broadleaved trees, in purported ECM association with the widespread, natively sand-growing littoral seagrape, Coccoloba uvifera (L.) L. (Polygonaceae), a small woody plant naturally distributed throughout the Caribbean basin (Séne et al. 2015, 2018). This notable species appears to be the first and sole red-pored bolete recorded in the Dominican Republic so far and one of the very few ECM members of the Boletaceae to be found in local lowland deciduous forested ecosystem.

The present paper is one in a series of intended contributions devoted to the study of neotropical Boletales, aiming to provide new insights into the taxonomy, phylogenetic relationships, plant and substrate associations, ecological importance, conservation and biogeographic patterns of the bolete communities occurring in the Dominican Republic, with continued biodiversity investigations of underexplored areas.

\section{Materials and methods}

\section{Collection site and sampling}

Specimens examined were collected in a hilly forest near the cemetery of Sousa, in Puerto Plata Province, Dominican Republic, and are deposited in the Herbarium of Jardín Botánico Nacional of Santo Domingo, Dr. Rafael Ma. Moscoso (JBSD) (acronym from Thiers 2019), while "ANGE" and "MG" refer to the personal herbarium of Claudio Angelini and Matteo Gelardi, respectively. Herbarium numbers are cited for all collections from which morphological features were examined. Author citations follow the Index Fungorum, Authors of Fungal Names (www.indexfungorum.org/authorsoffungalnames.htm). 


\section{Morphological studies}

Macroscopic descriptions and ecological information, such as habitat notations, time of fruiting and associated plant communities accompanied the detailed field notes of the fresh basidiomata. Color terms in capital letters (e.g. Myrtle Green, pl. VIII) are from Ridgway (1912). Photographs of collections were taken in the natural habitat using a Nikon Coolpix 8400 digital camera. Microscopic anatomical features were observed and recorded from revived dried material; sections were rehydrated either in water, $5 \%$ potassium hydroxide $(\mathrm{KOH})$ or in anionic solution saturated with Congo red. All anatomical structures were observed and measured from preparations in anionic Congo red. Colors and pigments were described after examination in water and $5 \% \mathrm{KOH}$. Measurements were made at $1000 \times$ using a calibrated ocular micrometer (Nikon Eclipse E200 optical light microscope). Basidiospores were measured directly from the hymenophore of mature basidiomes, dimensions are given as (minimum) average \pm standard deviation (maximum), $Q=$ length/width ratio with the extreme values in parentheses, $\mathrm{Qm}=$ average quotient (length/width ratio) \pm standard deviation and average spore volume was approximated as a rotation ellipsoid $[\mathrm{V}=(\pi . \mathrm{L} . \mathrm{W} 2) / 6 \pm$ standard deviation]. The notation $[\mathrm{n} / \mathrm{m} / \mathrm{p}]$ indicates that measurements were made on " $\mathrm{n}$ " randomly selected basidiospores from " $\mathrm{m}$ " basidiomes of "p" collections. The width of each basidium was measured at the widest part, and the length was measured from the apex (sterigmata excluded) to the basal septum. Metachromatic, cyanophilic and iodine reactions were tested by staining the basidiospores in Brilliant Cresyl blue, Cotton blue and Melzer's reagent, respectively. Line drawings of microstructures were traced in free-hand based on digital photomicrographs of rehydrated material.

\section{DNA extraction, PCR amplification and DNA sequencing}

Genomic DNA was isolated from $10 \mathrm{mg}$ of four dried herbarium specimen (Table 1), by using the DNeasy PlantMini Kit (Qiagen, Milan Italy) according to the manufacturer's instructions. PCR amplifications were performed with the primers ITS1F/ITS4 for the nrITS region (White et al. 1990, Gardes and Bruns 1993), LR0R and LR5 for the nrLSU region (Vilgalys and Hester 1990) and the reverse complement of bRPB2-6R2 (Matheny et al. 2007) and bRPB2-7.1R2 (5'- CCCATNGCYTGYTTVCCCATDGC -3') or RPB2-B-F1 and RPB2-B-R (Wu et al. 2014) for partial rpb2. Amplification reactions were performed in a PE9700thermal cycler (Perkin-Elmer, Applied Biosystems) following Vizzini et al. (2015). The PCR products were purified with the AMPure XP kit (Beckman Coulter) and sequenced by MACROGEN Inc. (Seoul, Republic of Korea). The sequences were submitted to GenBank (http://www.ncbi.nlm.nih.gov/genbank/) and their accession numbers are reported in Table 1. 
Table I. Samples sequenced for the present study.

\begin{tabular}{lcccc}
\hline \multicolumn{1}{c}{ Species } & \multicolumn{3}{c}{ GenBank acc. number } & Source, date and country \\
\cline { 2 - 4 } & nrITS & nrLSU & rpb2 & \\
\hline Neoboletus antillanus & MK388290 & MK388302 & MK488082 & JBSD127417 (holotype), 14/12/2014, \\
& & & & Dominican Republic \\
Neoboletus antillanus & MK388291 & MK388302 & - & JBSD127416, 03/12/2013, Dominican Republic \\
Neoboletus antillanus & MK388292 & - & - & JBSD127418, 01/12/2017, Dominican Republic \\
Boletus brunneopanoides & MK388293 & MK512677 & - & BOS 389 (CFMR, holotype), 21/10/2002, Belize \\
\hline
\end{tabular}

\section{Sequence alignment, data set assembly and phylogenetic analyses}

The sequences obtained in this study were checked and assembled using Geneious v. $\mathrm{R}$ 11.1.4 (Kearse et al. 2012) and compared to those available in GenBank database (https://www.ncbi.nlm.nih.gov/genbank/) by using the BLASTN algorithm (Altschul et al. 1990). A general combined Maximum likelihood tree including all the Boletaceae sequences present in GenBank and UNITE (http://unite.ut.ee/) databases was generated to detect the phylogenetic position of our collections in the major clades of Boletaceae as circumscribed by Wu et al. (2014) (tree not shown). Consequently, phylogenetic analyses were restricted to the major clade including Neoboletus sequences (Pulveroboletus group, Fig. 1).

Our datasets consist of sequences of Neoboletus and other sequences with greatest similarity available in GenBank selected based on BLASTN search and previous molecular studies including Neoboletus collections (Wu et al. 2014, 2016a, b; Smith et al. 2015; Urban and Klofac 2015).

Sequences were aligned with MAFFT v. 7.017 (Katoh et al. 2002) and then manually adjusted using Geneious v. R 11.1.4 (Kearse et al. 2012). Two phylogenetic analyses were performed: the first phylogenetic analysis, based on a combined nrLSU/ rpb1/rpb2 dataset, was focused on the intergeneric position of the new species in the Pulveroboletus group of the Boletaceae, as delimited by Wu et al. (2014). According to the results by Wu et al. (2014), Zangia erythrocephala was chosen as outgroup taxon for the three-loci combined dataset. The second phylogenetic analysis based only on a nrITS sequence dataset was restricted to the taxa closely related to the new species (genus Neoboletus). Costatisporus cyanescens was used as outgroup taxon for this dataset following Smith et al. (2015).

The GTRGAMMA model of sequence evolution was selected for both analyses. The two phylogenetic analyses were inferred with three partitions: $\mathrm{nrLSU}(28 \mathrm{~S}) / \mathrm{rpb}$ 1/ $r p b 2$ and ITS1/5.8S/ITS2, respectively. The datasets were analyzed using Bayesian inference (BI) and Maximum likelihood (ML) criteria. The BI was performed with $\mathrm{Mr}$ Bayes v.3.2 (Ronquist et al. 2012) with four incrementally heated simultaneous Monte Carlo Markov Chains (MCMC) run for 10 million generations, under the selected evolutionary model. Trees were sampled every 1000 generations, resulting in overall 


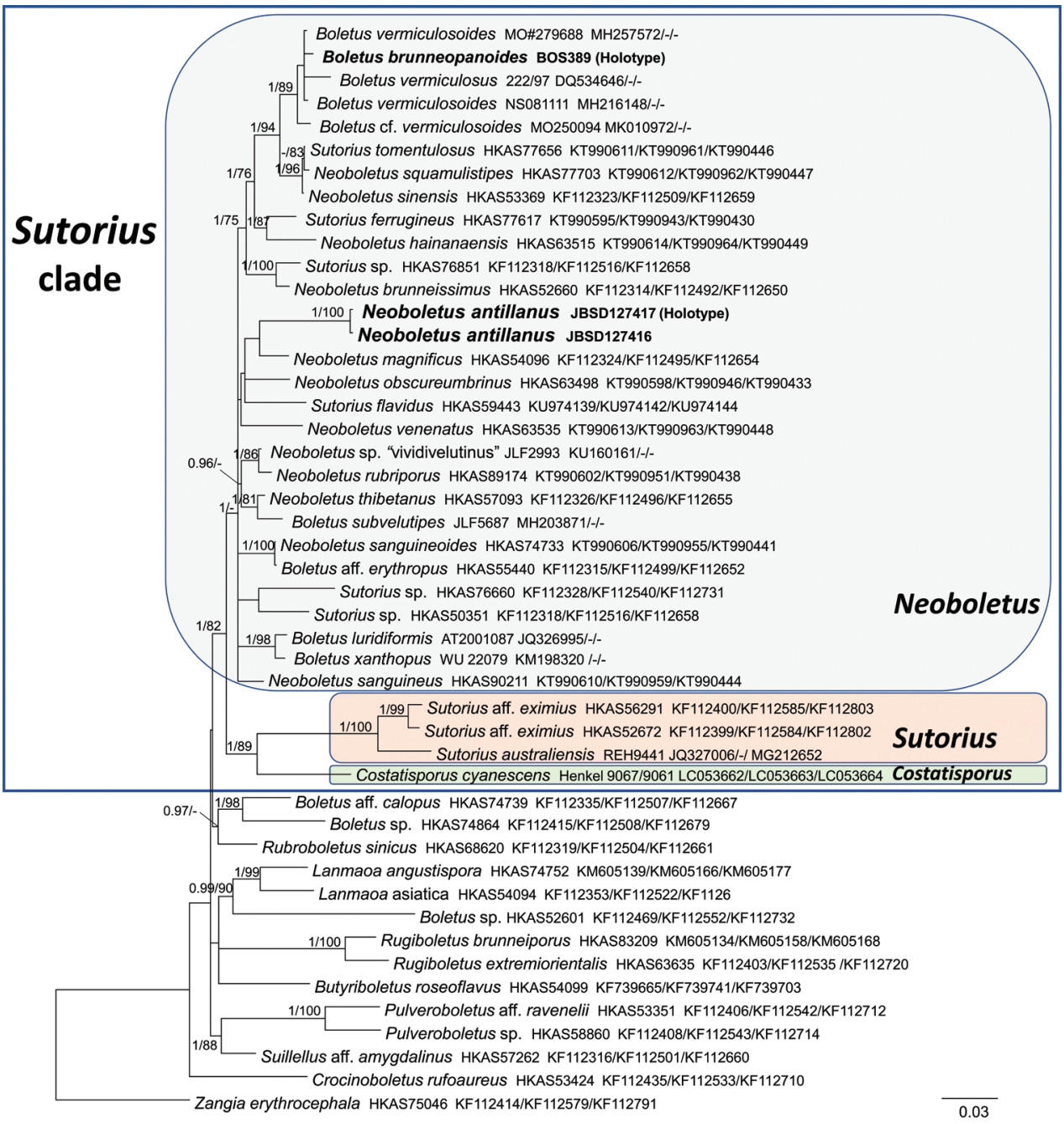

Figure I. Phylogeny of the Pulveroboletus group based on a Bayesian and Maximum-likelihood inference analysis of a matrix of concatenated sequences from three nuclear gene regions (nrLSU/28S, rpb1 and rpb2). Zangia erythrocephala was used as outgroup taxon. Values for clades that are supported in either the Bayesian (posterior probabilities, BPP) and Maximum likelihood (ML bootstrap percentage, MLB) analyses are indicated. BPP $\geq 0.95$ and $\mathrm{MLB} \geq 70 \%$ are given above clade branches. Newly sequenced collections are boldfaced in black. For each collection, the specific epithet (as present in GenBank), the herbarium code and GenBank accession numbers of the nrLSU/rpb1/rpb2 sequences are reported.

sampling of 10001 trees; the first 2500 trees were discarded as "burn-in" (25\%). For the remaining trees, a majority rule consensus tree showing all compatible partitions was computed to obtain estimates for Bayesian Posterior Probabilities (BPP). The ML was performed with RAxML v.7.2.8. (Stamatakis 2006) and a total of 1000 bootstrap replicates (Felsenstein 1985) were computed to assess the relative robustness of the 
branches. Only BPP values $\geq 0.95$ and MLB (Maximum likelihood bootstrap) values $\geq 70 \%$ have been reported in the phylogenetic trees (Figs 1,2). Pairwise \% identity values of the sequences were calculated using Geneious v. R 8.1.2 (Kearse et al. 2012). Alignments and phylogenetic trees are available at Tree-BASE (www.treebase.org, submission number S24011).

\section{Results}

\section{Molecular analysis}

The combined nrLSU/rpb1/rpb2 data matrix (focused on the Pulveroboletus group) comprised 47 sequences and is 2381 bp long. The nrITS data matrix (focused on $\mathrm{Ne}$ oboletus) comprised 41 sequences and is $830 \mathrm{bp}$ long. As the topology and branches support values of all the analyses are consistent, only the Bayesian trees with both BPP and MLB values are shown (Figs 1,2). In the combined analysis (Fig. 1) a major clade is recognizable ( $\mathrm{BPP}=1, \mathrm{MLB}=82 \%$ ), here named as the Sutorius clade, where the two sister $(\mathrm{BPP}=1, \mathrm{MLB}=89 \%)$ genera Sutorius and Costatisporus are sister $(\mathrm{BPP}=1$, MLB $=82 \%$ ) to the genus Neoboletus. The two collections of the new species clustered together within the genus Neoboletus forming a strongly supported clade (BPP $=1$, MLB $=100 \%$ ) which is sister (with no support) to $N$. magnificus. In the nrITS analysis (Fig. 2) the three collections of the new species ( $N$. antillanus) clustered together in a strongly supported clade $(\mathrm{BPP}=1, \mathrm{MLB}=100 \%)$ which shows no clear phylogenetic affinities with other species. The three nrITS sequences (677 to $683 \mathrm{bp}$ ) and the two nrLSU sequences ( 840 to $857 \mathrm{bp}$ ) of $N$. antillanus show a pairwise \% identity value of 99.7 and 100, respectively. The type specimen of Boletus brunneopanoides from Belize forms: i) a strongly supported clade $(\mathrm{BPP}=1, \mathrm{MLB}=89 \%)$ with also two collections of B. vermiculosoides, one collection of Boletus cf. vermiculosoides and one of B. vermiculosus, in the combined analysis; ii) a strongly supported clade (BPP $=1, \mathrm{MLB}=100 \%)$ with also two collections of B. vermiculosoides, one collection of Boletus cf. vermiculosoides and one of Boletales sp. (KY826093), in the nrITS analysis.

\section{Taxonomy}

Neoboletus antillanus Angelini, Gelardi, Costanzo \& Vizzini, sp. nov.

Figs 3, 4

Mycobank MB829549

Etymology, the specific epithet antillanus (Latin) refers to the occurrence of the species in the Antilles islands of the Caribbean.

Original diagnosis. Basidiomes stipitate-pileate with tubular hymenophore characterized by medium-small size, pinkish red to reddish pileus surface, orange-red pores, 


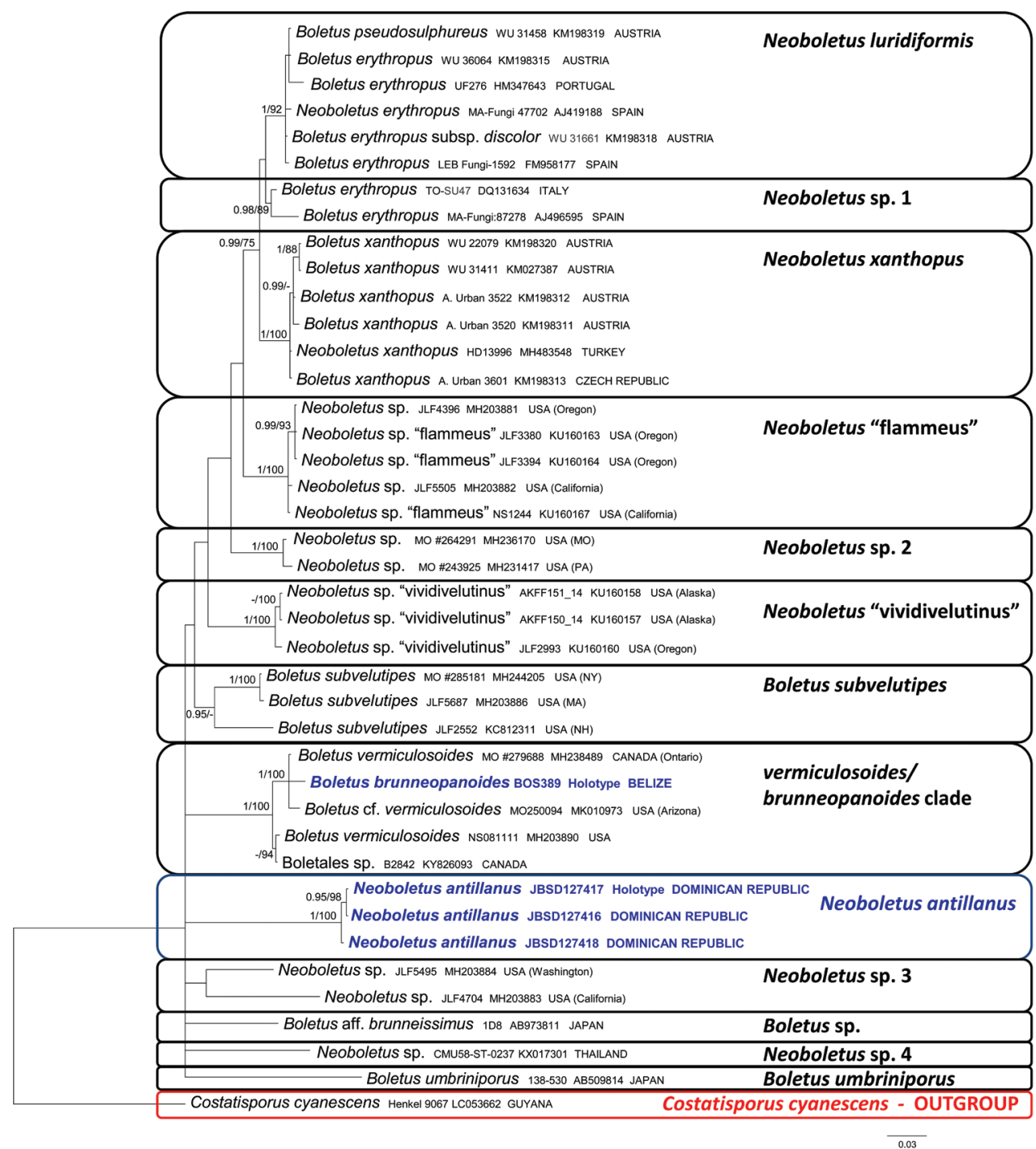

Figure 2. Bayesian phylogram obtained from the nrITS sequence alignment of Neoboletus species. Costatisporus cyanescens was used as outgroup taxon. Values for clades that are supported in either the Bayesian (posterior probabilities, BPP) and Maximum likelihood (ML bootstrap percentage, MLB) analyses are indicated. BPP $\geq 0.95$ and MLB $\geq 70 \%$ are given above clade branches. Newly sequenced collections are boldfaced in blue. For each collection, the specific epithet (as present in GenBank), the herbarium code, GenBank accession number of the nrITS sequence and geographical origin (country) are reported.

reddish orange to purple-red punctuations on a yellow stipe surface, golden yellow strigosity at the stipe base, yellow context, tissues bruising dark blue when injured or exposed, ellipsoid-fusiform, smooth basidiospores, ixocutis pileipellis consisting of gelatinized, repent filamentous hyphae and occurrence in neotropical lowland mixed 
broadleaved forests in putative ECM association with host species (Coccoloba uvifera) other than Fagaceae and Pinaceae.

Holotypus. DOMINICAN REPUBLIC, Municipality of Sousa, Puerto Plata Province, Loc. Cemetery, 1944'40"N, 70³2'21"W, 100 m a.s.l., 14 Dec 2014, C. Angelini (JBSD127417; isotypus ANGE434 and MG719).

Basidiomes medium-small (Fig. 3). Ontogenetic development gymnocarpic. Pileus (3.0) 3.5-7.5 (8.0) cm broad, at first hemispherical then persistenly convex and finally broadly pulvinate-flattened, sometimes slightly depressed at centre, regularly to hardly unevenly shaped, moderately fleshy, firm at the beginning but progressively softer with age, flabby in old basidiomes; margin steady to faintly wavy-lobed, initially involute then curved downwards, extending beyond the tubes up to $1 \mathrm{~mm}$; surface matt, dry but slightly greasy with moist weather, very finely tomentose, not cracked; cuticle somewhat variable in color, ranging from wine red, dark red or reddish pink to pastel pink (Pomegranate Purple, pl. XII; Spinel Red, pl. XXVI; Pinkish Vinaceous, pl. XXVII; Carmine, Eosine Pink, Geranium Pink, Rose Doree, pl. I; Alizarine Pink, Jasper Pink, Old Rose, pl. XIII), gradually fading with age and becoming pinkish cream to pale ochraceous pink (Flesh Pink, pl. XIII; Pale Ochraceous-Salmon, Pale Ochraceous-Buff, Light Buff, Light Ochraceous-Buff, Warm Buff, pl. XV) with olive-brown to brownish shades (Dresden Brown, pl. XV; Olive Lake, pl. XVI; Light Yellowish Olive, Buffy Olive, pl. XXX) tending to progressively spread from the center towards the peripheral zone; slowly bluing (Methy Green, Sea Green, Prussian Green, pl. XIX; Motmot Blue, Capri Blue, pl. XX) on handling or when injured; subcuticular layer cream-yellowish (Citrine Yellow, pl. XVI). Tubes at first thin then increasingly broader and as long as or slightly longer than the thickness of the pileus context at maturity (up to $1.0 \mathrm{~cm}$ long), adnate but soon deeply depressed around the stipe apex, occasionally subdecurrent, bright yellow (Lemon Chrome, pl. IV) to olive-yellow (Yellowish Citrine, pl. XVI), turning blue (Prussian Green, Duck Green, Invisible Green, pl. XIX) when cut and eventually fading to drab yellowish (Aniline Yellow, Pyrite Yellow, pl. IV). Pores initially forming a concave then flat surface, at first small then gradually wider (up to $1 \mathrm{~mm}$ in diam.), simple, roundish to barely angular at maturity, at first bright orangered to orange (Scarlet Red, Scarlet, pl. I) although concolorous with the tubes (Lemon Chrome, pl. IV) towards the margin, soon becoming yellowish orange (Flame Scarlet, Orange Chrome, pl. II) and finally yellowish olive (Yellowish Citrine, pl. XVI) with very pale orange hues (Orange, pl. III), quickly and intensely turning blue (Prussian Green, Duck Green, Invisible Green, pl. XIX) on bruising or when injured. Stipe (3.5) 4.0-9.0 (9.5) $\times(1.0) 1.5-2.0(2.5) \mathrm{cm}$, longer than or as long as the pileus diameter at maturity, central to slightly off-center, solid, firm, dry, straight or curved, at first ventricose-fusiform, later cylindrical but either sligthly swollen towards the base to decidedly clavate or tapering downwards, not to barely rooting, evelate; surface at the apex or in the upper third usually smooth to occasionally very faintly reticulate due to the sub-decurrence of the hymenophore in some specimens and bright yellow (Lemon Chrome, pl. IV) to lemon yellow (Strontian Yellow, pl. XVI), elsewhere showing a fine, purple-red, dark red to orange-red (Indian Lake, pl. XXVI; Amaranth Purple, pl. 

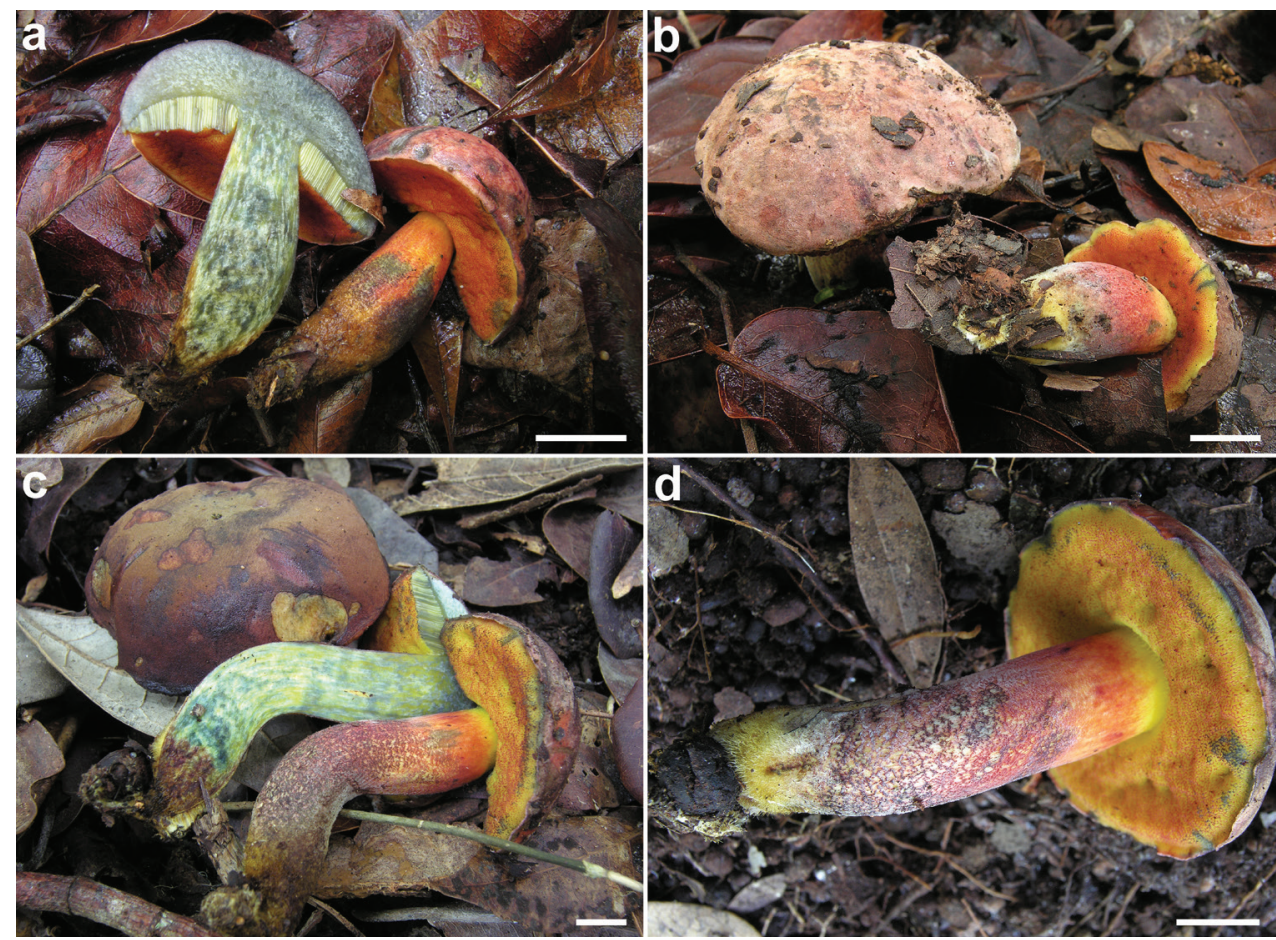

Figure 3. Neoboletus antillanus. Basidiomata in situ. a JBSD127416 b JBSD127417 (holotype) c, d JBSD127418. Scale bars: $1 \mathrm{~cm}$. Photos by C. Angelini.

XII; Carmine, Scarlet Red, pl. I) punctuation (Fig. 2d) partly hiding the bright yellow (Lemon Chrome, pl. IV) ground color; the base is typically wrapped by a conspicuous golden yellow to brownish yellow strigosity (Fig. 2d) (Raw Sienna, pl. III; Yellow Ocher, pl. XV); bruising greenish blue (Light Blue Green, Blue Green, Forest Green, pl. XVII) throughout when pressed; basal mycelium golden yellow (Raw Sienna, pl. III; Yellow Ocher, pl. XV). Context firm when young, later soft textured and eventually flabby in the pileus (up to $1.0 \mathrm{~cm}$ thick in the central zone), a little more fibrous in the stipe, lemon yellow (Strontian Yellow, pl. XVI) throughout, usually with purplebrown (Indian Lake, pl. XXVI; Amaranth Purple, pl. XII) spots in the stipe, especially at the extreme base; turning blue (Methy Green, Sea Green, Prussian Green, pl. XIX; Motmot Blue, Capri Blue, pl. XX) more or less evenly when exposed to air and finally fading to drab yellowish (Aniline Yellow, Pyrite Yellow, pl. IV); subhymenophoral layer lemon yellow (Strontian Yellow, pl. XVI). Odour and taste not distinctive. Spore-print not obtained but likely olive-brown.

Basidiospores [102/5/3] (8.8) $11.1 \pm 0.78(12.7) \times(4.1) 4.9 \pm 0.26(6) \mu \mathrm{m}, \mathrm{Q}=$ (1.85) 1.96-2.54 (2.57), $\mathrm{Qm}=2.24 \pm 0.12, \mathrm{~V}=143 \pm 23 \mu \mathrm{m}^{3}$, inequilateral, ellipsoidfusiform to ellipsoid in side view, ellipsoid in face view, smooth, apex rounded, with a short apiculus and with a shallow suprahilar depression, moderately thick-walled $(0.5-0.9 \mu \mathrm{m})$, honey yellow colored in water and $5 \% \mathrm{KOH}$, having one or two large 

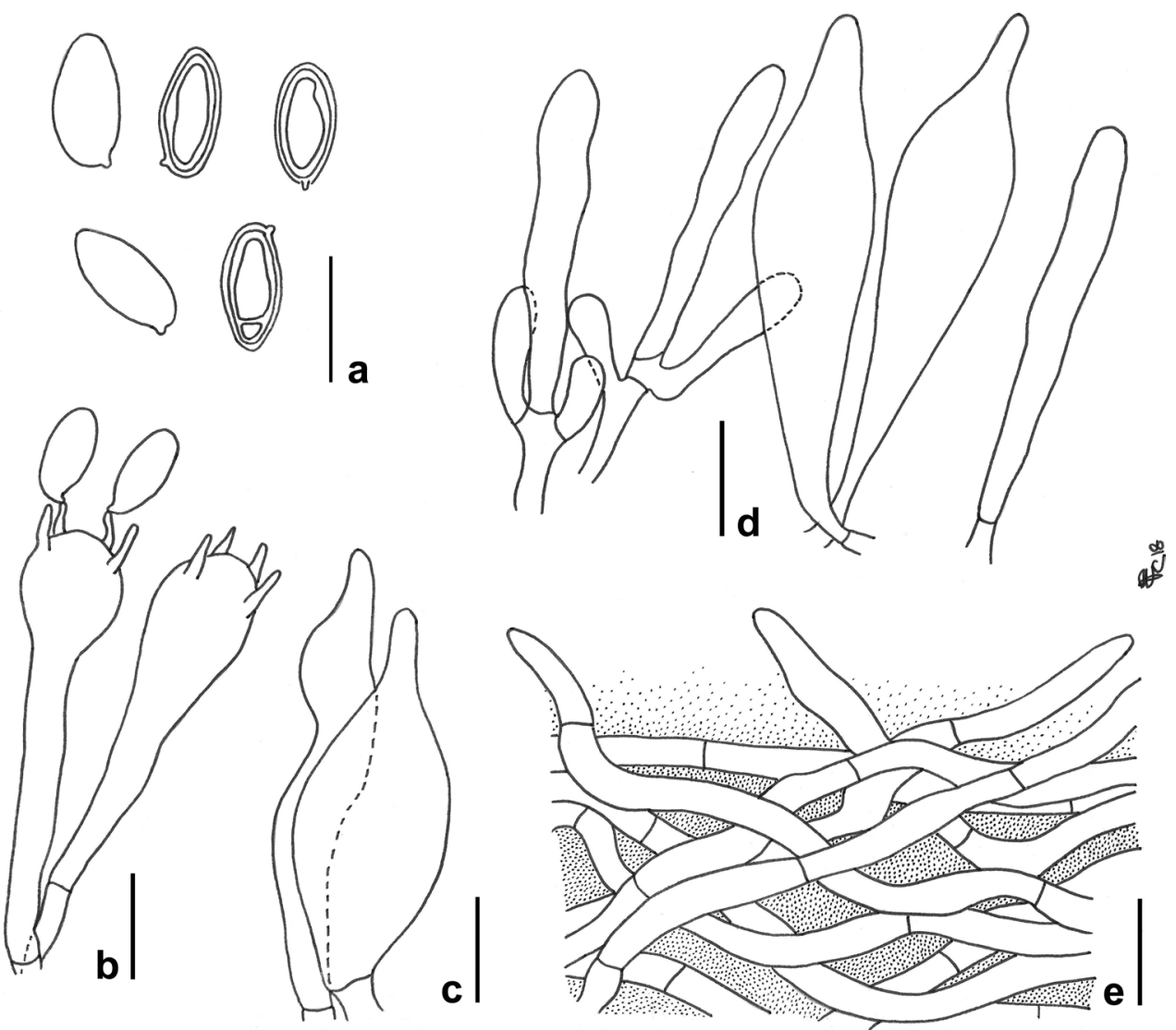

Figure 4. Neoboletus antillanus. Micromorphological features (JBSD127417) a Basidiospores b Basidia c Caulocystidia d Cheilo- and pleurocystidia e Elements of the pileipellis. Scale bars: $10 \mu \mathrm{m}(\mathbf{a}-\mathbf{d})$; $20 \mu \mathrm{m}(\mathbf{e})$. Drawings by F. Costanzo.

oil droplets when mature, rarely pluri-guttulate, inamyloid to very faintly dextrinoid, acyanophilic and with an ortochromatic to very faint metachromatic reaction (Fig. 4a). Basidia 24-48 × 10-13 $\mu \mathrm{m}(\mathrm{n}=26)$, cylindrical-clavate to clavate, moderately thick-walled $(0.5-0.8 \mu \mathrm{m})$, predominantly 4 -spored but also 1 - or 2-spored, usually bearing relatively short sterigmata $(2-6 \mu \mathrm{m})$, hyaline to pale yellowish and containing straw-yellow oil guttules in water and $5 \% \mathrm{KOH}$, bright yellow (inamyloid) in Melzer's, without basal clamps (Fig. 4b); basidioles subcylindrical to faintly clavate, similar in size to basidia. Cheilocystidia (19) 21-56 × 4-9 (11) $\mu \mathrm{m}(\mathrm{n}=23)$, very common, moderately slender, projecting straight to sometimes flexuous, irregularly cylindrical or cylindrical-fusiform, fusiform to narrowly lageniform, showing a narrow and long neck, with rounded to subacute tip, smooth, moderately thin- to slightly thick-walled $(0.3-0.9 \mu \mathrm{m})$, hyaline to pale yellowish in water and $5 \% \mathrm{KOH}$, bright yellow (inamyloid) in Melzer's, without epiparietal encrustations (Fig. 4d). Pleurocystidia (41) 44-55 $\times 5-11 \mu \mathrm{m}(\mathrm{n}=14)$, uncommon, shape, color and chemical reactions similar to but 
usually longer than cheilocystidia (Fig. 4d). Pseudocystidia not recorded. Pileipellis (Fig. $4 \mathrm{e})$ an ixocutis consisting of strongly interwoven, elongated, filamentous and sinuous, frequently branched, repent to occasionally erect hyphae heavily embedded in gelatinous matter; terminal elements 20-72 $\times 3-9 \mu \mathrm{m}$, long and slender, cylindrical, apex pointed, moderately thick-walled (up to $1 \mu \mathrm{m}$ ), pale yellow to golden yellow in water and $5 \% \mathrm{KOH}$, inamyloid in Melzer's, smooth to sometimes ornamented by a subtle zebra-like epiparietal encrustation; subterminal elements similar in shape, size and color to terminal elements. Stipitipellis a texture of slender, parallel to subparallel and longitudinally running, smooth-walled, adpressed hyphae, 3-11 $\mu \mathrm{m}$ wide, hyaline to yellowish in water and $5 \% \mathrm{KOH}$; the stipe apex covered by a well-developed caulohymenial layer consisting of sterile clavate caulobasidioles, abundant, predominantly 4- or 2-spored, fertile caulobasidia and projecting, irregularly cylindrical or cylindricalfusiform, ventricose-fusiform to fusiform, sublageniform to rarely short mucronate caulocystidia (Fig. 4c) similar in shape and color to but slightly broader than hymenial cystidia, (23) $25-45(54) \times 5-13(15) \mu \mathrm{m}(\mathrm{n}=16)$, having a wall up to $0.8 \mu \mathrm{m}$ thick. Lateral stipe stratum under the caulohymenium present and well differentiated from the stipe trama, of the "boletoid type", at the stipe apex a (20) 30-40 (50) $\mu \mathrm{m}$ thick layer consisting of divergent, inclined and running towards the external surface, loosely intermingled and branched hyphae remaining separate and embedded in a gelatinous substance. Stipe-trama composed of densely arranged, subparallel to moderately interwoven, frequently septate, cylindrical to filamentous, smooth, inamyloid hyphae, 4-13 $\mu \mathrm{m}$ broad. Basal tomentum hairs $40-150 \mu \mathrm{m}$ thick, consisting of tightly adpressed, parallel to subparallel, septate, filamentous, occasionally branched, relatively thick-walled (up to $0.8 \mu \mathrm{m}$ ) hyphae, $2-5.5 \mu \mathrm{m}$ wide, terminal elements with blunt apex, pale yellow to honey yellow in water and $5 \% \mathrm{KOH}$. Hymenophoral trama bilateral divergent of the "Boletus-type", with slightly to strongly divergent, recurved-arcuate and loosely arranged, often branched, restricted at septa, gelatinous hyphae (lateral strata hyphae in transversal section not touching each other, (2) 4-8 (10) $\mu \mathrm{m}$ apart, 3-13 $\mu \mathrm{m}$ broad), hyaline to very pale yellowish in water and $5 \% \mathrm{KOH}$, inamyloid in Melzer's; lateral strata (20) 30-50 (60) $\mu \mathrm{m}$ thick, mediostratum (20) 30-60 (70) $\mu \mathrm{m}$ thick, axially arranged, consisting of a tightly adpressed, non-gelatinous bundle of hyphae, 3-10 $\mu \mathrm{m}$ broad; in Congo Red the mediostratum is darker than the lateral strata. Thromboplerous hyphae (= oleiferous hyphae sensu Clémençon 2004) very common and particularly frequent in the hymenophore, golden yellow in $5 \% \mathrm{KOH}$. Clamp-connections absent everywhere. Hyphal system monomitic.

Ecology. solitary to gregarious, growing on limestone among litter in a seasonally dry and moist anthropised lowland mixed stand under a large array of neotropical broadleaved trees, including Coccoloba uvifera, which represents its probable ECM host tree. See Parra et al. (2018) for further details on vegetation.

Edibility. Unknown.

Examined material. DOMINICAN REPUBLIC, Municipality of Sousa, in Puerto Plata Province, Loc. Cemetery, $19^{\circ} 44^{\prime} 40^{\prime \prime N}, 70^{\circ} 32^{\prime} 21^{\prime \prime W}, 100$ m a.s.l., a single middle-aged specimen, 03 Dec 2014, C. Angelini (JBSD127416, ANGE425 
and MG718); same loc., two young to mature specimens, 14 Dec 2014, C. Angelini (JBSD127417, Holotype, ANGE434 and MG719, Duplo); same loc., several dozens of specimens, most of which heavily parasitized by Hypomyces sp., 01 Dec 2017, C. Angelini (JBSD127418, ANGE958 and MG720).

Known distribution. Presently only known from the type locality in the Dominican Republic (Greater Antilles, Caribbean).

\section{Discussion}

\section{Neoboletus antillanus phylogeny and interspecific relationships}

Phylogenetic analyses corroborate the proposal of the new species $N$. antillanus (Figs 1, 2). It forms an independent evolutive line within Neoboletus with no evident phylogenetic relationships (it is sister to the Chinese $N$. magnificus in the combined analysis, but without statistical support) to allied congeneric taxa. According to the same analyses, $B$. brunneopanoides, a Belizean red-pored bolete species phylogenetically nested in Neoboletus, clustered in the same clade with collections named B. vermiculosus/B. vermiculosoides from North America. Should future molecular work prove conspecificity among these three species, B. vermiculosus Peck would have priority.

\section{Taxonomic circumscription of $N$. antillanus}

The genus Neoboletus currently encompasses fewer than ten species geographically restricted to the northern hemisphere and essentially distributed in temperate and tropical regions. However, judging from morphological traits, there might be an additional number of species, up to three times as many in fact, belonging to the same genus, most of which have not yet been molecularly investigated. It is worth noting that a group of Chinese researchers after having firstly accepted Neoboletus as an independent genus (Wu et al. 2016a), have subsequently reduced it in synonymy with Sutorius Halling, Nuhn \& Fechner based on a wider interpretation of the generic boundaries within the Boletaceae (Wu et al. 2016b). As previously pointed out by Gelardi (2018), we presently disagree with this broad circumscription of Sutorius since it is, judging from the original description, easily separated from Neoboletus based on the overall dark colors, different stipe ornamentation pattern, different spore print color, pores stuffed in early developmental stages like those of Boletus s. str. and Butyriboletus Arora \& J.L. Frank and non-bluing tissues (Halling et al. $2012 b)$. Enough, in our opinion, to state they are not the same thing especially because they cluster in two different (although with a low statistical support) sister clades. Moreover, molecular studies carried out by Smith et al. (2015) on false-truffle fungi from north-eastern South America (Guyana) and our nrLSU/rpb1/rpb2 analy- 
sis (Fig. 1) indicate the sequestrate genus Costatisporus T.W. Henkel \& M.E. Smith as the sister taxon to Sutorius. Costatisporus, Neoboletus and Sutorius form the Sutorius clade (Fig. 1).

Neoboletus antillanus is easily identifiable among other species of the same genus based on the following set of unique morphologically informative features: 1) mediumsmall size, 2) reddish to pinkish red then pinkish cream pileus surface, 3) pores orange red to yellowish orange, 4) stipe ornamented over the lower three fourth by purple-red to reddish orange punctuations on a yellow background, 5) lowermost part of the stipe prominently strigose with golden yellow to brownish yellow hairs, 6) yellow context, 7) tissues bruising dark blue when injured, 8) ellipsoid-fusiform, smooth basidiospores, 9) ixocutis pileipellis consisting of gelatinized, repent filamentous hyphae and 10) occurrence in neotropical lowland mixed broadleaved forests. To date, $N$. antillanus has never been found with host species other than local autoctonous broadleaved trees and does not appear to be associated with either Pinaceae or Fagaceae (the latter plant family is not present in Dominican Republic). Moreover, such a purported ECM association of $N$. antillanus with the endemic $C$. uvifera might implicate a neotropical origin. Further suggestion supporting a symbiotic relationship between $N$. antillanus and $C$. uvifera is the co-occurrence at the same locality with Cantharellus coccolobae Buyck, P.A. Moreau and Courtec., which is strictly associated with seagrape in tropical America (Buyck et al. 2016).

Among the other endemic red-pored boletes reported from Central America, Boletus pyrrhosceles Halling, B. guatemalensis R. Flores \& Simonini, B. dupainii Boudier and $B$. paulae J. García, Singer \& F. Garza-Ocañas superficially resembles $N$. antillanus. However, $B$. pyrrhosceles is easily separated by the reddish brown to brownish orange pileus surface, adnate to subdecurrent hymenophore, shallow tubes (up to 5 $\mathrm{mm}$ deep), brownish red pores, tomentose and reticulate stipe that is entirely brownish red to deep red, slightly smaller basidiospores $(9.1-11.2 \times 4.2-4.9 \mu \mathrm{m}, \mathrm{Qm}=$ 2.3), trichodermal pileipellis and association with Quercus humboldtii Bompl. in Colombia (Halling 1992). Boletus guatemalensis has a whitish to pale yellow context with yellowish green spots towards the stipe base, radially elongated angular pores, stipe surface with brownish green fibrils in the lower half and a smooth, whitish base, white basal mycelium, unchanging tissues, mostly 2- or 3-spored basidia, a cutis pileipellis consisting of non-gelatinized hyphae, hymenophoral trama intermediate between the "Boletus-type" and the "Phylloporus-type" and is associated with Pinus caribaea Morelet in Guatemala, Belize and Mexico (Flores Arzù and Simonini 2000, Ortiz-Santana et al. 2007, García-Jiménez et al. 2013). Boletus dupainii s. OrtizSantana et al. differs in the larger size (pileus up to $13 \mathrm{~cm}$ broad), polish and shiny, carmine red to crimson red pileus surface, deep red pores, stipe base devoid of strigosity, longer spores $(12.8-14.4 \times 4-5.6 \mu \mathrm{m}, \mathrm{Qm}=2.9)$, smaller basidia $(24-29.6 \times$ 9.6-10.4 $\mu \mathrm{m})$, shorter pleuro-, cheilo- and caulocystidia $(26.4-47.2 \times 7.2-8.8 \mu \mathrm{m}$, $16-30.4 \times 4.8-8 \mu \mathrm{m}$ and $16-36.8 \times 5.6-11.2 \mu \mathrm{m}$, respectively), thinner pileipellis hyphae (up to $6.5 \mu \mathrm{m}$ diam.) and growth in symbiosis with Quercus spp. in Belize 
(Ortiz-Santana et al. 2007). This species has recently been assigned to Rubroboletus Kuan Zhao \& Zhu L. Yang on account of morphological and molecular evidence (Zhao et al. 2014). It was originally described from Europe (Boudier 1902) where it appears to be widespread although uncommon, but in recent times it has also been reported from the New World (McConnell and Both 2002, Ortiz-Santana et al. 2007, Both et al. 2009, García-Jiménez 2013, Bessette et al. 2016). However, the conspecificity of the European material with that from the western hemisphere is yet to be confirmed and a comparative analysis is currently under examination. Finally, $B$. paulae exhibits a deep red, vinaceous red to strawberry red pileus surface, smooth stipe base, whitish gray basal mycelium, pale whitish yellow and erratically bluing context on exposure, hymeniform pileipellis consisting of chains of inflated to subglobose elements up to $34 \mu \mathrm{m}$ broad and ECM association with oaks in Mexico (García-Jiménez et al. 2013).

Although $N$. antillanus exhibits some superficial morphological affinities with Boletus vermiculosus Peck, B. vermiculosoides A.H. Smith \& Thiers and B. brunneopanoides $\mathrm{B}$. Ortiz, these three species have larger basidiome size (pileus 7-18 $\mathrm{cm}$ broad and stipe 9-14 cm long in B. vermiculosus, pileus up to $12 \mathrm{~cm}$ and $16 \mathrm{~cm}$ broad in $B$. vermiculosoides and $B$. brunneopanoides, respectively), subtomentose to velvety, yellowish brown or grayish brown to dark brown pileus surface, brownish orange to amber brown or dark brown pore surface fading brownish yellow with age, extremely fine brownish punctuations on stipe surface and stipe base without hairs. B. vermiculosus also differs from $N$. antillanus in the trichodermal pileipellis devoid of gelatinous matter, longer basidiospores [(11) 12.6-14 (15) x (4) 4.9-5.6 (6) $\mu \mathrm{m}, \mathrm{Qm}=2.6]$ and the occurrence under Fagaceae. B. vermiculosoides is further distinguished by the paler, whitish-yellow stipe surface, narrower basidiospores [9-12 × 3-3.5 (4) $\mu \mathrm{m}$ ], smaller basidia $(20-26 \times 7-9 \mu \mathrm{m})$ and association with Fagaceae, whereas B. brunneopanoides is also separated by the whitish stipe surface, narrower basidiospores $(8.8-12.8 \times 4$ $\mu \mathrm{m})$, smaller basidia $(20.4-32 \times 8-8.8 \mu \mathrm{m})$ and the occurrence with Pinaceae (P. caribaea) (Coker and Beers 1943, Smith and Thiers 1971, Both 1993, Bessette et al. 2000, 2016; Halling and Mueller 2005, Ortiz-Santana et al. 2007). Boletus vermiculosus and $B$. vermiculosoides were originally described from eastern North America but the former is also encountered in Central America south to Belize and Costa Rica (Bessette et al. 2000, 2016; Halling and Mueller 2005), while B. brunneopanoides was only found in Belize (Ortiz-Santana et al. 2007). Up to now, neither of these species has been reported from the Dominican Republic.

At least two additional North American boletes might be confused with $N$. antillanus, namely Boletus subluridus (Murrill) Murrill and B. fairchildianus (Singer) Singer. The combination of yellowish orange, orange-pink to purplish red pileus surface, dark red pores, non-strigose stipe base, slightly longer basidiospores [(8.5) 9-14(14.5) $\times$ (3.5) 4-6(7) $\mu \mathrm{m}$ ], smaller basidia $(20-25.5 \times 7.5-10 \mu \mathrm{m}$ and occurrence with oaks and pines in south-eastern USA differentiate $B$. subluridus from $N$. antillanus (Murrill 1938, Singer 1945, 1947, both as B. miniato-olivaceus var. subluridus Singer; Both 
1993, Bessette et al. 2000; 2016), whereas B. fairchildianus is distinguished by the larger size (pileus up to $15 \mathrm{~cm}$ broad), stipe base without strigosity, larger basidiospores [(12.5) 13-18.8 (19.7) $\times(4.5) 5-8 \mu \mathrm{m}]$ and the association with Quercus spp. in south-eastern USA and Mexico (Singer 1945, 1947, both as B. rubricitrinus var. fairchildianus Singer; Both 1993, Bessette et al. 2000, 2016; García-Jiménez 2013).

Neoboletus luridiformis (Rostk.) Gelardi, Simonini \& Vizzini (= Boletus erythropus Pers. s. Fr. et auct. p.p. non s. Pers.) differs significantly from $N$. antillanus in the large sized basidiomes (pileus up to $25-30 \mathrm{~cm}$ in diam.), dark chocolate brown to umber brown, velvety pileus surface, bright red pores, stout, fleshy stipe (up to $15 \times 8 \mathrm{~cm}$ ), non-strigose stipe base, longer basidiospores [(12.8) 13.3-15.5 (16.5) $\times 4.2-5.5 \mu \mathrm{m}$, $\mathrm{Qm}=2.95]$, trichodermal pileipellis with interwoven erect, non-gelatinous hyphae and occurrence in Europe in temperate regions (Pilát and Dermek 1974, Alessio 1985, Breitenbach and Kranzlin 1991, Lannoy and Estadès 2001, Muńoz 2005, Watling and Hills 2005, Klofac 2007, Knudsen and Taylor 2012; pers. obs.).

The eastern Asian species N. brunneissimus (W.F. Chiu) Gelardi, Simonini \& Vizzini and $N$. antillanus share some common features such as basidiome size, presence of golden yellow to brownish yellow strigosity at the stipe base, yellowish context and dark blue staining of tissues by auto-oxidation but the former is readily separated by the velvety and rusty brown to umber-brown pileus cuticle, rusty brown to reddish-brown pores, denser and rusty-brown punctuation on stipe surface, trichoderm pileipellis consisting of non-gelatinized erect hyphae with slightly shorter and narrower terminal elements [23-45 (58) $\times 3.5-5(7) \mu \mathrm{m}]$ and the occurrence in East Asia in association with Fagaceae and Pinaceae (Chiu 1948, 1957; Bi et al. 1997, Mao 2000, 2009; Wang and Liu 2002, Wang 2004, Wang et al. 2004; Zang 2006, Wu et al. 2016a, Gelardi 2018).

The Chinese N. magnificus (W.F. Chiu) Gelardi, Simonini \& Vizzini, Sutorius sanguineoides G. Wu \& Zhu L. Yang and S. sanguineus G. Wu \& Zhu L. Yang are three additional eastern Asian species that may be confused with $N$. antillanus. Aside from the different geographical distribution and the ECM deciduous and coniferous host associates (Fagaceae and Pinaceae), the former species is also delimited by the dark red to reddish brown pores in the early developmental stages, a decidedly clavate to bulbous stipe base (up to $6 \mathrm{~cm}$ broad) that is devoid of or sometimes with inconspicuous strigosity and non-gelatinized trichodermal pileipellis with broader end elements (up to $16 \mu \mathrm{m}$ wide) (Chiu 1948, 1957; Bi et al. 1997, Mao 2000, 2009; Wang 2004, Wang et al. 2004, Zang 2006, Wu et al. 2016a), whereas S. sanguineoides and S. sanguineus are both separated from $N$. antillanus on account of the deep red, blood red to brownish red pileus surface, dark red to brownish red pores, non-strigose stipe base, non-gelatinized trichodermal pileipellis and the occurrence in subalpine forests at very high elevations (over $3000 \mathrm{~m}$ alt.) (Wu et al. 2016b). Furthermore, S. sanguineoides differs in its decidedly larger basidiospores [13.5-17 $(21) \times 5-7 \mu \mathrm{m}, \mathrm{Qm}=2.56]$ while $S$. sanguineus also exhibits an evenly red stipe surface, slightly longer basidiospores [10-14 (15) $\times 5-6(7) \mu \mathrm{m}, \mathrm{Qm}=2.14]$ and broader cystidioid pileipellis terminal cells (9-15 $\mu \mathrm{m}$ wide) (Wu et al. 2016b). 


\section{Acknowledgments}

CA wishes to thank Ricardo G. García, Francisco Jiménez, Brígido Peguero, Yuley E. Piñeyro and Alberto Veloz (Jardín Botánico Nacional Dr. Rafael M. Moscoso, Santo Domingo, Dominican Republic) for their interest and encouragement in studying fungi of the Dominican Republic and for their active cooperation in providing herbarium material preserved in their institution. Roy E. Halling (New York Botanical Garden, New York, USA) is acknowledged for providing valuable bibliography concerning Central American boletes.

\section{References}

Alessio C (1985) Boletus Dill. ex L. Fungi Europaei 2, Giovanna Biella, Saronno, 705 pp.

Alphonse ME (1981) Les champignons comestible d'Haiti. Faculte d' Agronomie et de Medecine Veterinaire, Damien, Port au Prince.

Altschul SF, Gish W, Miller W, Myers EW, Lipman DJ (1990) Basic local alignment search tool. Journal of Molecular Biology 215: 403-410. https://doi.org/10.1016/S00222836(05)80360-2

Arora D, Frank JL (2014) Clarifying the butter Boletes: a new genus, Butyriboletus, is established to accommodate Boletus sect. Appendiculati, and six new species are described. Mycologia 106(3): 464-480. https://doi.org/10.3852/13-052

Baker RED, Dale WT (1951) Fungi of Trinidad and Tobago. Mycological Papers 33: 1-123

Berkeley MJ, Curtis M (1868) (“1869”) Fungi Cubenses (Hymenomycetes). Journal of the Linnean Society, Botany 10: 280-392. https://doi.org/10.1111/j.1095-8339.1868.tb00529.x

Bessette AE, Roody WC, Bessette AR (2000) North American boletes. A color guide to the fleshy pored mushrooms. Syracuse University Press, Syracuse, 400 pp.

Bessette AE, Roody WC, Bessette AR (2016) Boletes of eastern North America. Syracuse University Press, Syracuse, 469 pp.

Bi Z-S, Li T-H, Zhang W-M, Song B (1997) A preliminary agaric flora of Hainan Province. Guangdong Higher Education Press, Guangzhou, 388 pp. (in Chinese)

Binder A (1999) Zur molekularen Systematische der Boletales: Boletineae und Sclerodermatineae subordo nov. PhD Dissertation, Universität Regensburg, Regensburg, 149 pp.

Binder M, Bresinsky A (2002) Derivation of a polymorphic lineage of Gasteromycetes from boletoid ancestors. Mycologia 94(1): 85-98. https://doi.org/10.2307/3761848

Binder M, Hibbet DS, Larsson KH, Larsson E, Langer E, Langer G (2005) The phylogenetic distribution of resupinate forms across the major clades of mushroom-forming fungi (Homobasidiomycetes). Systematics and Biodiversity 3(2): 113-157. https://doi.org/10.1017/ S1477200005001623

Binder M, Hibbett DS (2006) Molecular systematics and biological diversification of Boletales, Mycologia 98(6): 971-981. https://doi.org/10.3852/mycologia.98.6.971

Both EE (1993) The boletes of North America. A compendium. Buffalo Museum of Science, Buffalo, 436 pp. 
Both EE, Brown S, Ortiz-Santana B (2009) The second record of the European species, Boletus dupainii, in North America. Bulletin of the Buffalo Society of Natural Sciences 38: 1-4.

Boudier ELÉ (1902) Champignons nouveaux de France. Bulletin de la Société Mycologique de France 18: 137-146.

Breitenbach J, Kränzlin F (1991) Pilze der Schweiz. Band 3. Röhrlinge und Blätterpilze 1 Fungi of Switzerland. Vol. 3. Boletes and agarics 1. Verlag Mykologia, Luzern, 361 pp.

Bruns TD, Palmer JD (1989) Evolution of mushroom mitochondrial DNA: Suillus and related genera. Journal of Molecular Evolution 28(4): 349-362. https://doi.org/10.1007/ BF02103431

Buyck B, Moreau P-A, Courtecuisse R, Kong A, Roy M, Hofstetter V (2016) Cantharellus coccolobae sp. nov. and Cantharellus garnieri, two tropical members of Cantharellus subg. Cinnabarinus. Cryptogamie, Mycologie. 37(3): 391-403. https://doi.org/10.7872/crym/ v37.iss3.2016.391

Camino Vilaró M, Mena Portales J, Minter DW (2006) Fungi of Cuba. www.cybertruffle.org. uk/cubafung

Chakraborty D, Das K, Baghela A, Singh SK, Dentinger BTM (2015) Boletus recapitulatus (Boletaceae), a new species from India with peculiar mushroom-shaped cells. Phytotaxa 236(2): 150-160. https://doi.org/10.11646/phytotaxa.236.2.4

Chiu W-F (1948) The Boletes of Yunnan. Mycologia 40(2): 199-231. https://doi.org/10.108 $0 / 00275514.1948 .12017700$

Chiu W-F (1957) Atlas of the Yunnan Boletes - Bolete Flora of Yunnan. Science Press, Beijing, 154 pp. [In Chinese]

Clémençon H (2004) Cytology and plectology of the Hymenomycetes. Bibliotheca Mycologica 199: 1-488.

Coker WC, Beers AH (1943) The Boletaceae of North Carolina. University of North Carolina Press, Chapel Hill, 96 pp.

Courtecuisse R, Welti S (2013) Liste préliminaire des Fungi recensés dans les îles françaises des Petites Antilles : Martinique, Guadeloupe et dépendances. II - Basidiomycètes non lamellés (espèces gastéroïdes, rouilles et charbons exclus). Documents Mycologiques 35: 47-173.

Dennis RWG (1970) Fungus flora of Venezuela and adjacent countries. Kew Bulletin Additional Series 3, Royal Botanic Garden, Kew, 531 pp.

Desjardin DE, Binder M, Roekring S, Flegel T (2009) Spongiforma, a new genus of gastroid boletes from Thailand. Fungal Diversity 37: 1-8.

Farid A, Gelardi M, Angelini C, Franck AR, Costanzo F, Kaminsky L, Ercole E, Baroni TJ, White AL, Garey JR, Smith ME, Vizzini A (2018) Phylloporus and Phylloboletellus are no longer alone: Phylloporopsis gen. nov. (Boletaceae), a new smooth-spored lamellate genus to accommodate the American species Phylloporus boletinoides. FUSE 2: 341-359. https:// doi.org/10.3114/fuse.2018.02.10

Felsenstein J (1985) Confidence limits on phylogenies: an approach using the bootstrap. Evolution 39: 783-791. https://doi.org/10.2307/2408678

Flores Arzù R, Simonini G (2000) Contributo alla conoscenza delle Boletales del Guatemala. Rivista di Micologia 43(2): 121-145. 
Flores Arzú R, Comandini O, Rinaldi AC (2012) A preliminary checklist of macrofungi of Guatemala, with notes on edibility and traditional knowledge. Mycosphere 3(1): 1-21. https://doi.org/10.5943/mycosphere/3/1/1

Franco-Molano AE, Aldana-Gómez R, Halling RE (2000) Setas de Colombia. Agaricales, Boletales y otros hongos: guía de campo. Colciencias, Universidad de Antioquia Medellín, Colombia, $156 \mathrm{p}$.

Galli R (2007) I Boleti, Atlante pratico-monografico per la determinazione dei boleti (3 ${ }^{\text {rd }}$ ed.). Dalla Natura, Milano, 296 pp.

García-Jiménez J (2013) Diversidad de macromicetos en el estado de Tamaulipas, México. PhD en Ciencias Naturales, Facultad de Ciencias Forestales, Universidad Autónoma de Nuevo León, Linares, México, 254 pp.

García-Jiménez J, Singer R, Estrada E, Garza-Ocańas F, Valenzuela R (2013) Dos especies nuevas del género Boletus (Boletales: Agaricomycetes) en México. Revista Mexicana de Biodiversidad 84: 152-162. https://doi.org/10.7550/rmb.31988

Gardes M, Bruns TD (1993) ITS primers with enhanced specificity for Basidiomycetes-application to the identification of mycorrhizae and rusts. Molecular Ecology 2: 113-118. https://doi.org/10.1111/j.1365-294X.1993.tb00005.x

Gelardi M (2018) Contribution to the knowledge of Chinese boletes. II. Aureoboletus thibetanus s. 1., Neoboletus brunneissimus, Pulveroboletus macrosporus and Retiboletus kauffmanii (Part I), Rivista Micologica Romana 102(3): 13-30.

Gelardi M, Vizzini A, Ercole E, Voyron S, Sun J-Z , Liu X-Z (2013) Boletus sinopulverulentus, a new species from Shaanxi Province (central China) and notes on Boletus and Xerocomus, Sydowia 65(1): 45-57.

Gelardi M, Simonini G, Ercole E, Davoli P, Vizzini A (2015) Cupreoboletus (Boletaceae, Boletineae), a new monotypic genus segregated from Boletus sect. Luridi to reassign the Mediterranean species B. poikilochromus. Mycologia 107(6): 1254-1269. https://doi. org/10.3852/15-070

Gómez LD, Singer R (1984) Veloporphyrellus, a new genus of Boletaceae from Costa Rica. Brenesia 22: 293-298.

Gómez LD (1996) (“1997”) Basidiomicetes de Costa Rica: Xerocomus, Chalciporus, Pulveroboletus, Boletellus, Xanthoconium (Agaricales: Boletaceae). In: Carranza J, Mueller GM (Eds) Fungi of Costa Rica: selected studies on ecology and biodiversity. Revista de Biología Tropical 44 (suppl. 4): 59-89.

Guzmán G, Ramírez-Guillén F, Miller Jr OK, Lodge DJ, Baroni TJ (2004) Scleroderma stellatum versus Scleroderma bermudense: the status of Scleroderma echinatum and the first record of Veligaster nitidum from the Virgin Islands. Mycologia 96(6): 1370-1379. https://doi.or g/10.1080/15572536.2005.11832886

Halling RE (1989) A synopsis of Colombian Boletes. Mycotaxon 34: 93-113.

Halling RE (1992) A new species of Boletus section Luridi from Colombia. Brittonia 44(3): 322-325. https://doi.org/10.2307/2806931

Halling RE (1996) (“1997”) Boletaceae (Agaricales): Latitudinal biodiversity and biological interactions in Costa Rica and Colombia. In: Carranza J, Mueller GM (Eds) Fungi of Costa Rica: selected studies on ecology and biodiversity. Revista de Biologia Tropical 44 (Suppl. 4): 111-114. 
Halling RE, Mueller GM, Dallwitz MJ (1999) A new Phylloporus (Basidiomycetes, Boletaceae) with a key to species in Colombia and Costa Rica. Mycotaxon 63: 63-68.

Halling RE, Mueller GM (2002) Agarics and Boletes of Neotropical Oakwoods. In: Watling R, Frankland JC, Ainsworth AM, Isaac S, Robinson CH (Eds) Tropical Mycology. Vol. 1. Macromycetes, CAB International, Wallingford, 1-10.

Halling RE, Mueller GM (2003) Leccinum (Boletaceae) in Costa Rica. Mycologia 95(3): 488499. https://doi.org/10.2307/3761891

Halling RE, Mata M, Mueller GM (2004) Three new boletes for Costa Rica. Memoirs of the New York Botanical Garden 89: 141-147.

Halling RE, Mueller GM (2005) Common Mushrooms of the Talamanca Mountains, Costa Rica. Memoirs of the New York Botanical Garden Vol. 90, New York Botanical Garden Press, Bronx, 195 p.

Halling RE, Baroni TJ, Binder M (2007) A new genus of Boletaceae from eastern North America. Mycologia 99(2): 310-316. https://doi.org/10.3852/mycologia.99.2.310

Halling RE, Osmundson TW, Neves MA (2008) Pacific boletes: implications for biogeographic relationships. Mycological Research 112: 437-447. https://doi.org/10.1016/j. mycres.2007.11.021

Halling RE, Ortiz-Santana B (2009) A revision of Boletellus sect. Ixocephali. Mycological Progress 8: 237-244. https://doi.org/10.1007/s11557-009-0595-3

Halling RE, Nuhn M, Osmundson TW, Fechner NA, Trappe JM, Soytong K, Arora D, Hibbett DS, Binder M (2012a) Affinities of the Boletus chromapes group to Royoungia and the description of two new genera, Harrya and Australopilus. Australian Systematic Botany 25: 418-431. https://doi.org/10.1071/SB12028

Halling RE, Nuhn M, Fechner N, Osmundson TW, Soytong K, Arora D, Hibbett DS, Binder M (2012b) Sutorius: a new genus for Boletus eximius. Mycologia 104(4): 951-961. https:// doi.org/10.3852/11-376

Halling RE, Fechner N, Nuhn M, Osmundson TW, Soytong K, Arora D, Binder M, Hibbett DS (2015) Evolutionary relationships of Heimioporus and Boletellus (Boletales), with an emphasis on Australian taxa including new species and new combinations in Aureoboletus, Hemileccinum and Xerocomus. Australian Systematic Botany 28: 1-22. https://doi. org/10.1071/SB14049

Henkel TW, Obase K, Husbands D, Uehling JK, Bonito G, Aime MC, Smith ME (2016) New Boletaceae taxa from Guyana: Binderoboletus segoi gen. and sp. nov., Guyanaporus albipodus gen. and sp. nov., Singerocomus rubriflavus gen. and sp. nov., and a new combination for Xerocomus inundabilis. Mycologia 108(1): 157-173. https://doi.org/10.3852/15-075

Hitchcock AS (1898) List of cryptogams collected in the Bahamas, Jamaica and Grand Cayman. Annals and Reports of the Missouri Botanical Garden 9: 111-120. https://doi. org/10.2307/2992138

Hosford DR, Trappe JM (1980) Taxonomic studies on the genus Rhizopogon, II. Notes and new records of species from México and Caribbean countries. Boletin de la Sociedad Mexicana de Micología 14: 3-15.

Katoh K, Misawa K, Kuma K, Miyata T (2002) MAFFT: a novel method for rapid multiple sequence alignment based on fast Fourier transform. Nucleic Acids Research 30: 30593066. https://doi.org/10.1093/nar/gkf436 
Kearse M, Moir R, Wilson A, Stones-Havas S, Cheung M, Sturrock S, Buxton S, Cooper A, Markowitz S, Duran C, Thierer T, Ashton B, Meintjes P, Drummond A (2012) Geneious Basic: an integrated and extendable desktop software platform for the organization and analysis of sequence data. Bioinformatics 28: 1647-1649. https://doi.org/10.1093/bioinformatics/bts199

Klofac W(2007) Schlüssel zur Bestimmung von Frischfunden der europäischen Arten der Boletales mit röhrigem Hymenophor. Österreichische Zeitschrift für Pilzkunde 16: 187-279.

Knudsen H, Taylor AFS (2012) Boletales E.-J. Gilbert. In: Knudsen H, Vesterholt J (Eds) Funga Nordica - Agaricoid, boletoid and cyphelloid genera, Nordsvamp, Copenhagen, 149-179.

Kreisel K (1971) Clave para la identificacion de los macromicetos de Cuba. Ciencias Biológicas 16, Universidad de La Habana, Habana, 101 pp.

Lannoy G, Estadès A (2001) Flore Mycologique d'Europe 6 - Les Bolets. Documents Mycologiques, Mém. Hors Série 6, Lille, 163 pp.

Lécuru C, Courtecuisse R (2013) Liste préliminaire des Fungi recensés dans les îles françaises des Petites Antilles: Martinique, Guadeloupe et dépendances. III. Espèces gastéroïdes épigées relevant des Agaricomicetideae. Documents Mycologiques 35: 175-189.

Li Y-C, Feng B, Yang Z-L (2011) Zangia, a new genus of Boletaceae supported by molecular and morphological evidence. Fungal Diversity 49(1): 125-143. https://doi.org/10.1007/ s13225-011-0096-y

Liang Z-Q, An D-Y, Jiang S, Su M-S, Zeng N-K (2016) Butyriboletus hainanensis (Boletaceae, Boletales), a new species from tropical China. Phytotaxa 267(4): 256-262. https://doi. org/10.11646/phytotaxa.267.4.2

Lodge DJ, Baroni TJ, Miller Jr OK, Halling RE (2001) Emerging biogeographic patterns among macrobasidiomycete fungi in the Greater Antilles. In: Zanoni T (Ed.) Biogeography of Plants in the Greater Antilles, New York Botanical Garden, New York.

Mao X-L (2000) The Macrofungi of China. Henan Science and Technology Press, Zhengzhou, 719 pp. [In Chinese]

Mao X-L (2009) Macromycetes of China. Science Press, Beijing, 816 p. [In Chinese]

Mata M, Halling RE, Mueller GM (2003) Macrohongos de Costa Rica. Vol. 2. INBio, Santo Domingo, Costa Rica. 240 pp.

Matheny PB, Wang Z, Binder M, Curtis JM, Lim YW, Nilsson RH et al. (2007) Contributions of rpb2 and tef1 to the phylogeny of mushrooms and allies (Basidiomycota, Fungi). Molecular Phylogenetics and Evolution 43: 430-451. https://doi.org/10.1016/j.ympev.2006.08.024

McConnell OL, Both EE (2002) Boletus dupainii in North America. Field Mycology 3(3): 103-104. https://doi.org/10.1016/S1468-1641(10)60162-4

Mello A, Ghignone S, Vizzini A, Sechi C, Ruiu P, Bonfante P (2006) ITS primers for identification of marketable Boletes. Journal of Biotechnology 121: 318-329. https://doi. org/10.1016/j.jbiotec.2005.08.022

Miller Jr OK, Lodge DJ, Baroni TJ (2000) New and interesting ectomycorrhizal fungi from Puerto Rico, Mona, and Guana Islands. Mycologia 92(3): 558-570. https://doi. org/10.2307/3761516

Minter DW, Rodríguez-Hernández M, Mena-Portales J (2001) Fungi of the Caribbean. An annotated checklist, PDMS Publishing, Isleworth, $950 \mathrm{pp}$. 
Moreau P-A, Paz Conde A, Lavoise C, Curtecuisse R (2011) (“2013”) Les rhizomorphes de Diplocystis guadalupensis (Boletales, Sclerodermataceae). Bulletin de la Société Mycologique de France 127(3-4): 213-224.

Mueller GM, Halling RE, Carranza J, Mata M, Schmit JP (2006) Saprotrophic and ectomycorrhizal Macrofungi of Costa Rican oak forests. In: Keppelle M (Ed) Ecology and conservation of Neotropical montane oak forests. Springer-Verlag, Heidelberg, 55-68. https://doi. org/10.1007/3-540-28909-7_5

Muñoz JA (2005) Boletus s.l. (excl. Xerocomus). Fungi Europaei 2, Edizioni Candusso, Alassio, $952 \mathrm{pp}$.

Murrill WA (1910) A new Boletus from Jamaica. Mycologia 2(6): 305. https://doi. org/10.2307/3753294

Murrill WA (1918) The Agaricaceae of Tropical North America - VIII. Mycologia 10(2): 62 85. https://doi.org/10.2307/3753227

Murrill WA (1921) Notes and brief articles - A new bolete from Porto Rico. Mycologia 13(1): 60-61.

Murrill WA (1938) New boletes. Mycologia 30(5): 520-525. https://doi.org/10.1080/00275 514.1938.12017294

Nuhn ME, Binder M, Taylor AFS, Halling RE, Hibbett DS (2013) Phylogenetic overview of the Boletineae. Fungal Biology 117(7-8): 479-511. https://doi.org/10.1016/j.funbio.2013.04.008

Orihara T, Smith ME (2017) Unique phylogenetic position of the African truffle-like fungus, Octaviania ivoryana (Boletaceae, Boletales), and the proposal of a new genus, Afrocastellanoa. Mycologia 109(2): 323-332. https://doi.org/10.1080/00275514.2017.1301750

Ortiz-Santana B (2006) Phylogeny and biogeography of Caribbean Boletales. PhD Dissertation, University of Puerto Rico.

Ortiz-Santana B, Lodge DJ, Baroni TJ, Both EE (2007) Boletes from Belize and the Dominican Republic. Fungal Diversity 27: 247-416.

Parra AL, Angelini C, Ortiz-Santana B, Mata G, Billette C, Rojo C, Chen J, Callac P (2018) The genus Agaricus in the Caribbean. Nine new taxa mostly based on collections from the Dominican Republic. Phytotaxa 345(3): 219-271. https://doi.org/10.11646/phytotaxa.345.3.2

Patouillard NT (1900) Champignons de la Guadeloupe. Bulletin de la Société Mycologique de France 16: 175-188.

Patouillard NT (1902) Champignons de la Guadeloupe, recueillis par le R.P. Duss. Bulletin de la Société Mycologique de France 18: 171-186.

Pegler DN (1983) Agaric flora of the Lesser Antilles. Kew Bulletin Additional Series 9, HMSO, London, 668 pp.

Pegler DN (1987) Revision of Agaricales of Cuba. Kew Bulletin 42(3): 501-585. https://doi. org/10.2307/4110064

Pilát A, Dermek A (1974) Hríbovité huby. Československé hríbovité a sliziakovité huby (Boletaceae - Gomphidiaceae). Veda, Bratislava, 207 pp.

Reid DA (1977) Some Gasteromycetes from Trinidad and Tobago. Kew Bulletin 31(3): 657690. https://doi.org/10.2307/4119418

Ridgway R (1912) Color standards and color nomenclature. Self-published, Washington D.C. https://doi.org/10.5962/bhl.title.144788 
Ronquist F, Teslenko M, van der Mark P, Ayres DL, Darling A, Höhna S, Larget B, Liu L, Suchard MA, Huelsenbeck JP (2012) MrBayes 3.2: efficient Bayesian phylogenetic inference and model choice across a large model space. Systematic Biology 61: 539-542. https://doi.org/10.1093/sysbio/sys029

Séne S, Avril R, Chaintreuil C, Geoffroy A, Ndiaye C, Diédhiou AG, Sadio O, Courtecuisse R, Sylla SN, Selosse M-A, Bâ A (2015) Ectomycorrhizal fungal communities of Coccoloba uvifera (L.) L. mature trees and seedlings in the neotropical coastal forests of Guadeloupe (Lesser Antilles). Mycorrhiza 25(7): 547-559. https://doi.org/10.1007/s00572-015-0633-8

Séne S, Selosse M-A, Forget M, Lambourdière J, Cissé K, Diédhiou AG, Rivera-Ocasio E, Kodja H, Kameyama N, Nara K, Vincenot L, Mansot J-L, Weber J, Roy M, Sylla SN, Bâ A (2018) A pantropically introduced tree is followed by specific ectomycorrhizal symbionts due to pseudo-vertical transmission. The ISME Journal 12: 1806-1816. https://doi. org/10.1038/s41396-018-0088-y

Simonini G, Vizzini A (2015) Boletus mendax, una specie recentemente descritta in Italia ed i nuovi orientamenti sulla sistematica della sez. Luridi del genere Boletus. Numero speciale XL Mostra Reggiana del Fungo: 3-24.

Singer R (1945) New Boletaceae from Florida (a preliminary communication). Mycologia 37: 797-799. https://doi.org/10.2307/3755143

Singer R (1947) The Boletoideae of Florida. The Boletineae of Florida with notes on extralimital species III. The American Midland Naturalist 37(1): 1-135. https://doi. org/10.2307/2421647

Singer R, Fiard JP (1976) Agaricales nouvelles des Antilles françaises. Bulletin de la Société Mycologique de France 92(4): 445-447.

Singer R, Araujo I, Ivory MH (1983) The ectotrophically mycorrizal Fungi of the neotropical lowlands, especially Central Amazonia (Litter decomposition and ectomycorrhiza in Amazonian forests 2.). Beihefte zur Nova Hedwigia 77: 1-352.

Singer R, Gómez LD (1984) The Basidiomycetes of Costa Rica. III. The genus Phylloporus (Boletaceae). Brenesia 22: 163-181.

Singer R, García J, Gómez LD (1990) The Boletineae of Mexico and Central America I \& II. Beihefte zur Nova Hedwigia 98: 1-70.

Singer R, García J, Gómez LD (1991) The Boletineae of Mexico and Central America III. Beihefte zur Nova Hedwigia 102: 1-99.

Singer R, García J, Gómez LD (1992) The Boletineae of Mexico and Central America IV. Beihefte zur Nova Hedwigia 105: 1-62.

Smith ME, Amses KR, Elliott TF, Obase K, Aime MC, Henkel TW (2015) New sequestrate fungi from Guyana: Jimtrappea guyanensis gen. sp. nov., Castellanea pakaraimophila gen. sp. nov., and Costatisporus cyanescens gen. sp. nov. (Boletaceae, Boletales), IMA Fungus 6(2): 297-317. https://doi.org/10.5598/imafungus.2015.06.02.03

Stamatakis A (2006) RAxML-VI-HPC: maximum likelihood-based phylogenetic analyses with thousands of taxa and mixed models. Bioinformatic 22: 2688-2690. https://doi. org/10.1093/bioinformatics/btl446

Thiers B (2019) (continuously updated): Index Herbariorum: a global directory of public herbaria and associated staff. New York botanical garden's virtual herbarium. http://sweetgum. nybg.org/ih/ 
Trappe JM, Castellano MA, Halling RE, Osmundson TW, Binder M, Fechner N, Malajczuk N (2013) Australasian sequestrate fungi. 18: Solioccasus polychromus gen. and sp. nov., a richly colored, tropical to subtropical, hypogeous fungus, Mycologia 105(4): 888-895. https:// doi.org/10.3852/12-046

Urban A, Klofac W (2015) Neoboletus xanthopus, a sibling species of Neoboletus luridiformis and similar boletes with yellowish pileus colors. Sydowia 67: 175-187. https://doi. org/10.12905/0380.sydowia67-2015-0175

Vilgalys R, Hester M (1990) Rapid genetic identification and mapping of enzymatically amplified ribosomal DNA from several Cryptococcus species. Journal of Bacteriology 172: 42384246. https://doi.org/10.1128/jb.172.8.4238-4246.1990

Vizzini A (2014) Nomenclatural novelties. Index Fungorum 192: 1.

Vizzini A, Simonini G, Ercole E, Voyron S (2014) Boletus mendax, a new species of Boletus sect. Luridi from Italy, and insights on the B. luridus complex. Mycological Progress 13(1): 95-109. https://doi.org/10.1007/s11557-013-0896-4

Vizzini A, Consiglio G, Setti L, Ercole E (2015) Calocybella, a new genus for Rugosomyces pudicus (Agaricales, Lyophyllaceae) and emendation of the genus Gerhardtia. IMA Fungus 6(1): 1-11. https://doi.org/10.5598/imafungus.2015.06.01.01

Wang Q-B (2004) Taxonomy and molecular systematics of Boletus in China. PhD Dissertation, Systematic Mycology and Lichenology Laboratory, Institute of Microbiology, Chinese Academy of Sciences, Beijing, 214 pp. (in Chinese)

Wang X-H, Liu P-G (2002) Notes on several boleti from Yunnan, China. Mycotaxon 84: $125-134$.

Wang X-H, Liu P-G, Yu F-Q (2004) Color atlas of wild commercial mushrooms in Yunnan. Yunnan Science and Technology Press, Kunming, 136 pp. [In Chinese]

Watling R, Hills AE (2005) Boletes and their allies - Boletaceae, Strobilomycetaceae, Gyroporaceae, Paxillaceae, Coniophoraceae, Gomphidiaceae (revised and enlarged edition). In: Henderson DM, Watling R (Eds) British Fungus Flora, Agarics and Boleti, vol. 1, HMSO, Edinburgh, 174 pp.

White TJ, Bruns TD, Lee S, Taylor J (1990) Amplification and direct sequencing of fungal ribosomal RNA genes for phylogenetics. In: Innis MA, Gelfand DH, Sninsky JJ, White TJ (Eds) PCR protocols, a guide to methods and applications. Academic press, Orlando, 315-322. https://doi.org/10.1016/B978-0-12-372180-8.50042-1

Wu G, Feng B, Xu J-P, Zhu X-T, Li Y-C, Zeng N-K, Hosen I, Yang Z-L (2014) Molecular phylogenetic analyses redefine seven major clades and reveal 22 new generic clades in the fungal family Boletaceae. Fungal Diversity 69(1): 93-115. https://doi.org/10.1007/ s13225-014-0283-8

Wu G, Zhao K, Li Y-C, Zeng N-K, Feng B, Halling RE, Yang Z-L (2016a) Four new genera of the fungal family Boletaceae. Fungal Diversity 81(1): 1-24. https://doi.org/10.1007/ s13225-015-0322-0

Wu G, Li Y-C, Zhu X-T, Zhao K, Han L-H, Cui Y-Y, Li F, Xu J-P, Yang Z-L (2016b) One hundred noteworthy boletes from China. Fungal Diversity 81(1): 25-188. https://doi. org/10.1007/s13225-016-0375-8 
Zang M (2006) Boletaceae (I). Flora Fungorum Sinicorum Vol. 22, Science Press, Beijing, 205 pp. [In Chinese]

Zeng N-K, Cai Q, Yang Z-L (2012) Corneroboletus, a new genus to accommodate the southeast Asian Boletus indecorus. Mycologia 104(6): 1420-1432. https://doi.org/10.3852/11-326

Zhao K, Wu G, Yang Z-L (2014) A new genus, Rubroboletus, to accommodate Boletus sinicus and its allies. Phytotaxa 188(2): 61-77. https://doi.org/10.11646/phytotaxa.188.2.1

Zhao K, Wu G, Halling RE, Yang Z-L (2015) Three new combinations of Butyriboletus (Boletaceae). Phytotaxa 234(1): 51-62. https://doi.org/10.11646/phytotaxa.234.1.3

Zhu X-T, Li Y-C, Wu G, Feng B, Zhao K, Gelardi M, Kost G-W, Yang Z-L (2014) The genus Imleria (Boletaceae) in East Asia. Phytotaxa 191(1): 81-98. https://doi.org/10.11646/phytotaxa.191.1.5 